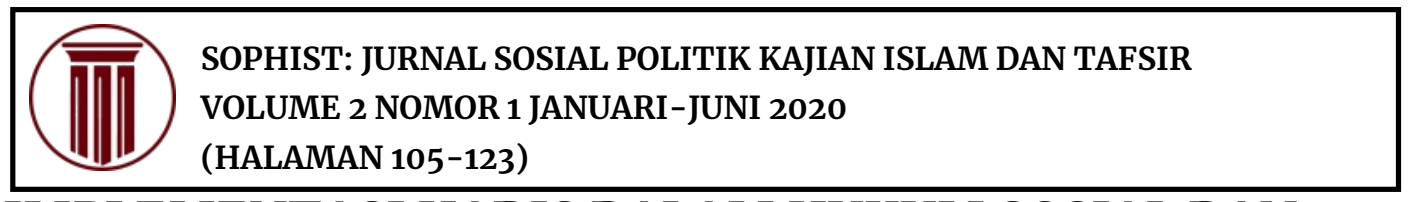

\title{
IMPLEMENTASI HADIS DALAM HUKUM SOSIAL DAN POLITIK
}

MOH. TAMIMI

UIN MATARAM

Tamimi28@uinmataram.ac.id

\section{Abstract}

This article aims to discuss the implementation of Prophet traditions (hadith) on law, social, and politic as part of the integration of science and religion. On this integration, hadith as a part of Islamic traditions emulsified its value with social and political aspects. Social sciences may in part coloring the interpretation of Hadith to formulate more contextual meaning that has been applied in various times and places..

Keywords: hadis, contextual, social, law, politic

\section{Abstrak}

Artikel ini bertujuan untuk membahas implementasi hadist Nabi di bidang hukum, sosial, dan politik sebagai bagian dari integrasi sains dan agama. Pada integrasi ini, hadis sebagai bagian dari tradisi Islam diemulsi nilainya dengan aspek sosial dan politik. Ilmu-ilmu sosial mungkin ikut mewarnai tafsir hadis untuk merumuskan makna yang lebih kontekstual yang telah diterapkan di berbagai tempat dan waktu.

Kata Kunci: Hadis, kontekstual, sosial, hukum, politik

\section{A. Pendahuluan}

Integrasi keilmuan islam dengan ilmu sosial politik diawali dengan proses reinterpretasi terhadap teks al-Quran dan hadis Nabi. Dua sumber utama ajaran Islam ini lantas menghasilkan cabang keilmuan seperti Ilmu Tafsir, Hadis, Fikih, Kalam, dan 
Tasawuf. Di sisi lain, keilmuan sosial berangkat dari dimensi kemanusian yang bersifat konkret dan terus dikembangkan oleh manusia itu sendiri. Ilmu eksakta maupun sosial-humaniora yang muncul dan mengalami pasang surut dalam ruang lingkup pemikiran manusia sebagai makhluk yang kasat mata.

Paradigma yang menyatukan dua jalur keilmuan yang memiliki dimensi berbeda ini tidak lantas mengecilkan peran Tuhan, yang berujung pada sekularisme atau mengucilkan peran manusia sehingga membuatnya terkucil dari dirinya sendiri dan masyarakat sekitar. Tetapi justru malah menghasilkan daya produktif dalam usaha mengkombinasikan dua kutub epistomologi yang berbeda.

Ucapan kepribadian dan perbuatan nabi Muhammad SAW merupakan pegangan dan uswah (suri tauladan) bagi kaum muslimin. Selain itu sejarah perjuangannya pun dijadikan motivasi bagi umat islam dalam melanjutkan dakwah menyebarkan amar makruf dan nahi mungkar. Oleh karena itu siapa saja yang ingin mengetahui metodologi keberhasilan perjuangan, karekateristik dan pokok-pokok ajaran nabi Muhammad SAW maka hal tersebut dapat dipelajari secara rinci dalam sunnah nabawiyah

Hadist Nabi Muhammad SAW selain sebagai sumber ajaran Islam yang kedua setelah al-Qur'an juga berfungsi sebagai sumber sejarah dakawah dan perjuangan rasululloh SAW, hadist juga mempunyai fungsi sebagai penjelas bagi al-Qur'an, menjelaskan yang global, menghususkan yang umum dan memberikan interprestasi terhadap ayat-ayat al-Qur'an 
Dalam interpretasi dengan corak tekstual ini, seorang penafsir dalam mengintrepretasikan Hadis Nabi saw membatasi pandangannya hanya terhadap teksnya saja, yaitu tidak mempertimbangkan konteks historis Hadis dan kaitannya dengan hal-hal kekinian yang sedang dihadapi umat Islam di mana dan kapan mereka berada. Para ulama tekstualis pada umumnya dari kalangan ahli Hadis yang produk fiqihnya diistilahkan dengan fiqh tradisional dan dipelopori oleh Imam Mâlik Bin Anas.

Penafsiran terhadap Hadîs dengan melihat konteks-historis yang kongkrit yakni dalam penafsiran Hadîs itu didasarkan atas analogi historis-kontekstual antara dunia Nabi Muhammad yang Arabik pada masa lima belas abad yang lalu dengan dunia umat Islam lain yang hidup di zaman serta wilayah yang berbeda, sehingga dapat mengimplimentasikan kandungan Hadis Nabi dalam konteks perkembangan kehidupan yang terus berjalan. Pandangan kontekstualisme selalu bersebrangan dan bahkan menolak terhadap setiap interpretasi tekstual yang memilah dan memutuskan antara fakta dimana dan kapan Nabi Muhamad saw hidup dengan realitas umat Islam sekarang.

Di dalam konteks kajian hadis, hadis memang sangat berbeda dengan al-Quran. Nuansa kemanusiaan yang terdapat di dalam hadis Nabi begitu mencolok dibandingkan dengan al-Quran. Dari segi sumber, al-Quran adalah murni wahyu Tuhan melalui malaikat Jibril tanpa adanya campur tangan Nabi, sedangkan hadis sebagian bersumber dari wahyu Tuhan atau ijtihad pribadi atas bimbingan wahyu dan sebagian lagi berdasarkan sisi kemanusiaan 
Nabi. Hal inilah yang barangkali menjadi alasan kuat integrasi ilmu-ilmu sosial dan hadis Nabi lebih pantas didahulukan daripada al-Quran, dengan tanpa mengurangi urgensitas al-Quran sebagai sumber pertama, sebab hadis lebih terasa kental dengan aspek kemanusiaannya. ${ }^{1}$

Dalam hal ini Hadis Nabi diposisikan sebagai objek material dan ilmu-ilmu sosial politik menjadi objek formalnya. Hadis Nabi di terjemahkan dengan pendekatan disiplin ilmu-ilmu sosial politik. Artikel ini diharapkan mampu meningkatkan gairah dalam mengkaji horizon keilmuan, sebagai bentuk upaya integrasi keilmuan yang digalakkan Universitas Islam Negeri Mataram.

\section{B.Corak Metode Interprestasi Hadist Dalam Istinbath Hukum Islam}

Terdapat beberapa metode dalam memahami hadis Nabi, berkaitan dengan ilmu Sejarah, Yūsuf al-Qaradhāwī misalnya, memberikan delapan langkah dalam berinteraksi dengan hadis Nabi. Di antaranya, pertama, memahami hadis sesuai dengan petunjuk al-Qur`an; kedua, mengumpulkan hadis-hadis yang setema (temati); ketia, kompromi atau tarjīh terhadap hadis-hadis yang kontradiktif; keempat, memahami hadis sesuai dengan latar belakang, situasi, dan kondisi serta tujuannya; kelima, membedakan antara sarana yang berubahubah dan tujuan yang tetap; keenam, membedakan antara ungkapan haqīqah dan majāz;

${ }^{1}$ Beni Afwadzi, Membangun Integrasi Ilmu-Ilmu Sosial dan Hadis Nabi, dalam Jurnal Living Hadis, Vol 1 No 1 Mei 2016 hal 105

108| Moh. Tamimi

JURNAL SOPHIST

Implementasi Hadist...

Vol. 2 No.1 Januari - Juni 2020 
ketujuh, membedakan antara yang gaib dan yang nyata; dan delapan, memastian makna kata-kata dalam hadis. ${ }^{2}$

Adanya dua bentuk interpretasi atau lebih terhadap Hadis tersebut menimbulkan konsekuensi dan ekses besar dalam pemikiran Islam, utamanya dalam produk hukum fiqih, misalnya perbedaan produk hukum fiqih madzhab Syâfi'î dengan produk madzhab Mâlikî, hal itu karena terdapat perbedaan manhaj dalam menginterpretasikan teks-teks agama (al Qur'an dan al-Sunnah). Imam Syâfi'î secara umum adalah kontekstualis sedangkan Imam Mâlik cendrung tekstualis. ${ }^{3}$

Terjadinya perbedaan pandangan antara para pakar dan pemikir muslim klasik itu menimbulkan implikasi besar terhadap corak pola pikir para tokoh masyarakat di Indonesia dalam menyikapi beberapa permasalahan kontemporer yang menimpa bangsa ini, di antaranya adalah :

\section{a. Kepemimpinan Wanita}

Berkenaan dengan masalah jender ini baginda Rasul saw telah bersabda dalam sebuah Hadisnya yang diriwayatkan oleh Imam Bukhari ${ }^{4}$ :

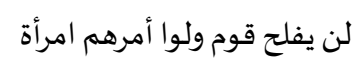

Artinya: "Tidak akan beruntung suatu kaum jika menyerahkan urusannya kepada perempuan".

\section{${ }^{2}$ Ibid}

${ }^{3}$ Harun Nasution, Islam Rasional, (Bandung: Mizan, 1995), hlm. 78 1990), hlm. 326

4 Al-Bukhâri, Shahîh al-Bukhârî, Juz 2 (Kairo: Mathba'ah Salafîyah, 
Dalam menyikapi hal tersebut muncul dua paradigma yang sangat berbeda antara kelompok yang melihat Hadis ini secara tekstual dengan kelompok lain yang memandang dari segi konteksnya. ${ }^{5}$ Di mana kelompok pertama yang tekstualis menyatakan bahwa sosok wanita sama sekali tidak boleh menempati posisi puncak kepemimpinan dalam pemerintahan pada sebuah negara, sebagaimana yang terjadi di Indonesia misalnya, dimana perempuan menempati kedudukan sebagai Presiden. Maka menurut pandangan kelompok yang pertama yang tekstualis bahwa hal tersebut tidak boleh dan dianggap menyalahi agama, karena kedudukan presiden sebagai posisi nomor satu dalam sebuah negara, dan memang secara tekstual Hadis tersebut menolak hal itu.

Dan dengan berlandaskan Hadis Nabi di atas pula, sebagian ulama memutuskan bahwa perempuan tidak boleh menduduki jabatan sebagai penegak hukum (al-hakim) kecuali dalam kondisi mendesak dan terpaksa (li al-dharûrah), dan jabatan kepala desa termasuk dalam kategori al-hakim juga. ${ }^{6}$ Maka dengan berdasarkan al-qiyâs al-awlâwî, lebih tidak boleh bagi sosok wanita untuk menempati jabatan yang lebih tinggi seperti bupati, gubernur dan apalagi jabatan presiden.

Sedangkan kelompok yang kedua yang kontekstualis tidak mempermasalahkan kepemimpinan wanita secara mutlak, baik

${ }^{5}$ Quraisy Syihab, Membumikan al-Qur 'an (Bandung: Mizan, 1998), hlm. 314

${ }^{6}$ Sebenarnya ini adalah masalah kontrofersi antara jumhur ( Madzhab Hanafi, Mâlikî, Syâfi'î, Hanbalî) dengan Ibnu Jarir al-Thobari 
pada kepemimpinan puncak ataupun kepemimpinan pada level di bawahnya. Kelompok ini memandang hadis tersebut dari segi konteksnya, di mana baginda Rasulullah dalam hadis ini menyoroti bangsa Persia yang dianggap kurang tepat dalam mengatur sistem pemerintahannya, karena mereka telah menempatkan sosok wanita pada posisi kepemimpinan puncak dalam pemerintahan, padahal kaum wanita di kalangan mereka pada saat itu sangat tertinggal dan terbelakang utamanya dalam dunia politik dan pendidikan, dan oleh karena itu dianggap tidak layak untuk menduduki posisi puncak dalam pemerintahan. Itulah sebabnya sehingga mendapat sorotan dari baginda Rasulullah. Maka menurut kelompok yang kedua Hadis ini, merupakan suatu koreksi terhadap bangsa persia yang telah keliru dalam memposisikan sosok wanita, dan bukan pelarangan terhadap kepemimpinan puncak bagi wanita dalam suatu negara.

Bertolak dari itu menurut kelompok yang kedua ini, tidak ada masalah bagi sosok wanita yang sudah memenuhi kriteria dan sudah mempunyai kelayakan, untuk menjabat sebagai seorang presiden dimana saja dan kapan saja. Di samping itu pula dalam konteks Indonesia bahwa presiden di negeri ini sebenarnya bukanlah pemimpin puncak, karena di atasnya masih ada kepemimpinan yang lebih tinggi sebagai pejabat tertinggi negara yaitu MPR.7

\section{b. Pembagian Harta}

7 Pernyatan KH. Hasyim Muzadi dalam sebuah acara Temu Kandidat Capres-Cawapres pada stasiun Lativi tanggal 20 Juni 20014 
Dalam pembagian harta warisan di Indonesia sudah berlaku satu sistem pembagian harta warisan (tirkat) yang disebut sistem gana-gini yang dianggap sebagai pengembangan dari sistem farâidh yang digariskan dengan berdasarkan nash (al-Qurân dan alhadis). Pola pembagian harta warisan dengan sistem gana-gini ini sudah diterapkan dan bahkan sudah menjadi tradisi pada sebagian kawasan di Indonesia. Dan penerapan sistem ini merupakan satu bentuk ijtihâd dari sebagian tokoh masyarakat (kyai) di Indonesia yang terpaksa dilakukan karena munculnya rasa ketidak puasan dari sebagian masyarakat awam terhadap sistem farâidh yang ada.

Fenomena ini termasuk bagian dari penerapan sistem yang sudah mengarah kepada pandangan yang kontekstual, yakni penerapan terhadap teks keagamaan dengan mempertimbangkan sosio kultural masyarakat yang ada, di mana suami dan isteri sama-sama bekerja, misalnya sama-sama pegawai negeri, pedagang, atau petani, bahkan kadang-kadang yang bekerja lebih berat justru sang isteri, berbeda sama sekali dengan sosio kultural masyarakat Arab pada masa lima belas abad silam di mana peran sang isteri pada masa itu pada umumnya hanya sebatas sebagai ibu rumah tangga saja.

Penulis melihat bahwa tanpa menggunakan sistem ganagini, sepertinya sulit sekali sistem farâidh untuk bisa diterima oleh masyarakat (masyarakat awam tentunya) pada kawasan tertentu di Indonesia.

Sebagian ulama membolehkan pembagian harta warisan dengan menggunakan sistem gana-gini tersebut, namun dengan 
syarat mendapat persetujuan dari para ahli waris. ${ }^{8}$ Artinya jika ada salah satu dari ahli waris yang mengadukan penerapan sistem ini, maka harus kembali kepada aturan pembagian harta warits sebagaimana yang diatur oleh ilmu farâidh.

Sementara kelompok yang berpandangan tekstual menolak terhadap penerapan gana-gini tersebut sebab dianggap menyalahi aturan yang digariskan oleh nash. Dalam artian tidak membuka peluang untuk ijtihâd dan pengembangan, seperti apapun bentuknya dan apapun alasannya, karena anggapan mereka bahwa aturan pembagian harta warisan itu sudah baku dan sudah paten berlaku untuk umat Islam dimanapun mereka berada dan kapan pun mereka hidup.

\section{Interprestasi Hadist Dan Implikasi Hukum Di Indonesia}

Kaitannya dengan masalah ini, cukup menarik paparan yang ditulis oleh Sjechul Hadi Permono, di mana beliau berpandangan bahwa teks-teks agama dapat dikategorikan kepada dua bentuk. Pertama, teks agama yang sifatnya dogmatis, yang tidak mungkin untuk diinterpretasikan secara kontekstual, sehingga hukum Islam yang diistimbathkan dari teks-teks semacam itu bersifat dogmatis pula yang tidak ada jalan bagi para fuqaha' untuk manambah ataupun menguranginya, dan dalam kategori yang pertama ini pintu ijtihâd tertutup. Kedua, ada pula teks agama yang terbuka untuk diinterpretasikan secara kontekstual, dan produk hukum

${ }^{8}$ Lajnah Ta'lif, Ahkamul Fuqaha', hlm , 38 
Islam yang diistinbathkannya pun masih membuka peluang terhadap upaya-upaya ijtihâd.

Dan untuk lebih jelasnya penulis akan memaparkan dua hal tersebut sebagai berikut:

\section{a. Bagian-Bagian Hukum Islam}

Hukum Islam yang dibawa oleh Nabi kita sangat luas ruang lingkupnya karena mencakup berbagai sisi kehidupan orang mukallaf, dan hukum Islam tersebut dapat dikategorikan kepada beberapa bidang :

1. Hukum Islam yang mencakup hal-hal ibadah seperti shalat, puasa, haji dan lain sebagainya yang bersifat dogmatis (unreasonable) merupakan bidang dimana kita tidak boleh menambah, merubah, mengurangi apa yang telah ada, dan tidak ada ruang ijtihâd di dalamnya. Bidang yang pertama ini diistilahkan dengan "syariah". 9

2. Hukum Islam yang mencakup hal-hal sosial kemasyarakatan dan transaksi dan lain sebagainya yang diistilahkan dengan fiqh mu'âmalah. Hukum Islam bidang kedua ini dibagi dua lagi yaitu :

a). Bidang mu'âmalah khâss yang merupakan ketentuan-ketentuan yang bersandar pada nashnash agama dari al-Qurân hadis yang qath'î (terinci, tegas dan pasti). Hukum mu'âmalah bidang ini

9 Sjechul Hadi Permono, Dinamisasi Hukum Islam dalam Menjawab Tantangan Era Globalisasi (Kudus: Pustaka Firdaus, 1998), hal:11 
termasuk kategori syarî'ah sama dengan bidang pertama yang sifatnya dogmatis, seperti hukumhukum pidana yang berbentuk sangsi-sangsi syara' (hudud) semacam qishâs, potong tangan dan jild (hukum cambuk) yang dalil syar'inya sudah jelas, shârih dan tidak mungkin dita'wil lagi. Dalam hal ini kaum muslim, baik kapasitas kita sebagai umat atau sebagai bangsa, harus menerima ketentuanketentuan tersebut menurut apa adanya, tidak perlu ditambah, dikurangi ataupun dirubah karena syara' menganggap bahwa itulah yang paling mashlahah untuk manusia.

b). Bidang mu'âmalah 'âmm (muamalah umum) yang merupakan ketentuan-ketentuan dengan bersumber pada nash-nash agama yang bersifat kullî, semisal hukum-hukum tata negara dan pemerintahan, bentuk-bentuk bertransaksi dalam dunia bisnis dan perekonomian dan lain sebagainya. Ruang ijtihâd dalam bidang ini sangat luas dan nalar akal pikiran sangat lincah tapi penuh tanggung jawab, dan tentunya ijtihâd melalui proses istinbath dengan metode dan sistematika yang shahîh (benar). Dalam hal ini al-'âdah dan al-'urf yang tidak bertentangan dengan nash-nash agama dapat dikukuhkan sebagai hukum Islam dalam kategori ini, tentu kita bisa 
mengembangkan sesuai situasi dan tuntutan kebutuhan zaman. Produk hukum ini disebut "fiqh ".10

b. Tajdid Sebuah Upaya Penggalian Hukum Islam

Upaya-upaya tajdîd ini tentunya dilakukan terhadap hukum-hukum Islam yang masih bisa memberi peluang terhadap upaya ijtihâd. Hal ini dilakukan dalam rangka untuk memberikan solusi terhadap penyelesaian masalah umat (bangsa), karena tanpa upaya tajdîd dengan selalu mengembangkan ijtihâd tersebut, maka peluang umat Islam untuk ikut serta berkiprah dalam upaya penyelesaian masalah sosial, ekonomi, politik, dan lain-lain akan berkurang, akibat ketidakmampuan menegejar perkembangan zaman yang berjalan cepat.

Kaitannya dengan masalah tajdîd tersebut, mengutip Syarah Ihyâ' Ulûm al-Dîn, Sjechul Hadi Permono mendefinisikan, yaitu¹"

$$
\text { "هو جعل الشيئ جديدا كالمبتدأ التجديد" }
$$

Artinya: Bahwa tajdîd adalah mengembalikan sesuatu menjadi baru sebagaimana mula pertama. Jadi pengertian tajdid di sini mengembalikan sesuatu kepada aslinya (orisinalnya) dan bukan mengganti dengan yang lain yang baru.

Lebih lanjut, ia mengatakan bahwa tajdîd dalam konteks hukum Islam harus memenuhi tiga unsur:

${ }^{10}$ Ibid

11 Sjechul Hadi Permono, Pembaruan Hukum Islam di Indonesia, Makalah disampaikan pada Konferensi Nasional Kajian Islam di Indonesia Tahun 2004 di Banda Aceh, tidak diterbitkan 
1. Al-ibânah (liberations) dalam arti bahwa dalam melakukan tajdid, kita dalam proses berpikir harus lepas dari fanatisme mazhab.

2. Al-i'âdah (reformations) artinya kita harus kembali kepada al-Qur'ân dan al-Hadis dengan menggunakan metode penggalian hukum yang benar.

3. Al-ihyâ' menyesuaikan dengan pergeseran kemaslahatan sebagai refleksi dari kemajuan ilmu pengetahuan modern dan teknologi dan tentunya yang tercakup dalam kemaslahatan-kemaslahatan yang menjadi tujuan syara'.

Berbicara masalah pembaruan hukum Islam, dalam Islam dikenal beberapa bentuk-bentuk hukuman pidana yang diistilahkan dengan ahkâm al-jarâ'im, yaitu hudud, qishâs, diyat, kaffarah, dan ta'zîr.

Dari bentuk-bentuk hukum pidana Islam tersebut, ada hukuman yang mengandung solidaritas sosial yaitu, diyat dan kaffarat.

Hukum pidana Islam yang mempunyai peluang untuk dikembangkan baik materi maupun cara-cara penegakannya adalah hukuman atas kejahatan yang tidak ditentukan bentuk dan kadar hukumannnya oleh nash al-Qurân dan al-Hadis.

Adapun bentuk-bentuk hukum pidana Islam yang sudah jelas ketentuannya dari syara', hanya dapat diperbarui dari dua sisi:

a. Sisi hukum formalnya, seperti cara-cara pembuktiannya, syarat-syarat formal hukuman bagi orang yang 
berbuat zina, dan syarat-syarat formal hukuman potong tangan dalam kasus pencurian.

b. Sisi perluasan makna teks sesuai dengan ilmu bahasa dan tujuan syariah seperti; pertama, kontekstualisasi kalimat أربعة شهداء (empat saksi) kepada أربع مرات (empat kali tertangkap basah walaupun oleh satu orang ). Kedua, perluasan makna سرقة (pencurian) dengan tidak dibatasi pada pencurian secara sembunyi sebagaimana dalam pegertian klasik.

\section{Respon atas Ragam Interpretasi Hadis}

Lepas dari menerima ataupun menolak, penulis memandang bahwa adanya dua paradigma dalam pola interpretasi (tekstualis dan kontekstualis) terhadap hadis Nabi, di samping mengandung segi-segi positif, tentu juga ada sisi negatifnya. Sisi Positifnya; pertama, Bagi kalangan intelektual, dua paradigma tersebut justru menambah khazanah pemikiran Islam yang sangat berharga. Kedua, dualisme interpretasi yang merupakan warisan dari para pemikir terdahulu itu menjadi modal yang cukup segnifikan dalam rangka dinamisasi pola pikir umat. Dimana upaya-upaya yang mengarah kepada rekonsiliasi sering kali kita lihat, yang dikemas dalam bentuk seminar-seminar, bahts al-masâil, simposium, dan sebagainya, sebagai upaya mencari titik temu. ${ }^{12}$ Ketiga, Penerapan analogi historis-kontekstual dalam memberikan interpretasi

12 Hal semacam itu tidak mungkin akan dilakukan tanpa muncul keragaman interpretasi yang terjadi antara para para ulama' dan para pemikir muslim 
terhadap Hadis Nabi akan lebih banyak memberikan peluang terhadap Islam untuk dapat memberikan solusi terhadap masalahmasalah kontemporer umat. ${ }^{13}$

Sedangkan sisi negatifnya, penerapan teori kontekstual sangat sulit untuk dipertemukan dengan teori tekstual. ${ }^{14}$ Fakta menunjukkan bahwa perbedaan interpretasi terhadap teks-teks agama itu menimbulkan perbedaan pandangan antar umat Islam pada tingkat menengah keatas, namun dalam perkembangannya akhirnya muncul perbedaan dan bahkan perpecahan antar kelompok pada level tengah kebawah. Mungkin masih segar dalam ingatan kita bagaimana pro dan kontra antara para pemikir muslim yang pernah terjadi di Indonesia pada tahun 80-an sehubungan dengan masalah bunga bank, pembagian harta waris, dan lain-lain.

Perpecahan pada level bawah ini sangat rentan terhadap munculnya tindakan-tindakan yang anarkhis, maka dengan demikian kesatuan umat yang selama ini kita dambakan hanyalah menjadi angan-angan belaka, mustahil untuk menjadi kenyataan. Jangankan perbedaan penafsiran terhadap teks-teks agama tidak akan menimbulkan masalah dalam tubuh umat ini, munculnya multi penafsiran terhadap teks proklamasi, Piagam jakarta dan UUD 45 sudah menimbulkan masalah dalam tubuh bangsa. Dimana setiap orang menklaim dirinya berhak memberikan interpretasi

${ }^{13}$ Lakspesdam NU, Tashwirul Afkar, Jurnal, edisi 8, hlm, 125

${ }_{14}$ Lorens Bagus, Kamus Filsafat (Jakarta: PT. Gramedia Pustaka Utama, 2002), hlm, 489. 
sesuai kehendaknya, maka yang terjadi adalah sangat sulit bagi bangsa ini untuk mencapai apa yang didambakannya.

Sebenarnya jika kita melihat jauh ke belakang, maka akan ditemukan bukti kongkrit yang menunjukkan bahwa pola interpretasi kontekstual terhadap Hadis Nabi sebenarnya sudah pernah diterapkan oleh sebagian para shahabat justru pada masa Baginda Rasul masih hidup. Dimana mereka dalam sebuah perjalanan bersama baginda Rasul, yaitu dalam peperangan alAhzab Beliau bersabda:'Jangan ada yang shalat Ashar kecuali di perkampungan Bani Quraizhah". Dalam memahami dan menyikapi Hadis ini, mereka yang ikut dalam perjalanan tersebut ada yang memahaminya dari segi tekstualnya, dan konsekwensi dari pemahaman tekstual tersebut mereka tidak melakukan sholat Ashar kecuali sesudah sampai di perkampungan Bani Quraizhah, karena teks Hadis tersebut menunjukkan hal itu.

Sementara yang memahaminya dari segi konteksnya tetap melakukan sholat Ashar di tempat sebelum melakukan perjalanan, dengan pertimbangan bahwa jika mereka sholat di perkampungan Bani Quraizhah dapat dipastikan akan terlambat sebab dipandang waktu tidak cukup melakukan sholat di perkampungan itu, sedangkan mengundur-undur sholat sampai keluar dari waktunya tanpa adanya 'udzur syar'î tidak dibenarkan menurut syari'at Islam. Dan Rasulullah menyikapi kedua pemahaman tersebut dengan bijaksana, bahwa apa yang dilakukan kedua kelompok ini 
sama-sama benar, satu kelompok memahami secara tekstual dan kelompok lain memahaminya secara kontekstual. ${ }^{15}$

\section{E.Kesimpulan}

Terdapat dua paradigma dalam menafsirkan Hadis Nabi, tekstualis dan kontekstualis. Bagi kalangan intelektual, dua paradigma tersebut justru menambah khazanah pemikiran Islam yang sangat berharga. Kedua, dualisme interpretasi yang merupakan warisan dari para pemikir terdahulu itu menjadi modal dinamisasi pola pikir umat. Ketiga, Implementasi analogi historiskontekstual lebih banyak memberikan peluang bagi ummat Islam untuk memberikan solusi terhadap masalah-masalah kontemporer umat.

Meskipun dalam penerapannya teori kontekstual sangat sulit untuk dipertemukan dengan teori tekstual. Perbedaan interpretasi terhadap teks-teks agama itu dapat menimbulkan perbedaan pandangan antar umat Islam pada akar rumput, namun dalam perkembangannya akhirnya muncul perbedaan. Perdebatan

15 Quriash Shihab, Membumikan al-Qur'ân, hlm, 125. Terdapat perbedaan lainnya, yaitu perbedaan antara Umar bin Khattab dengan para sahabat yang lain dalam sebuah perjalanan dikala mereka akan melintasi kawasan yang sedang dilanda penyakit menular (thâ'ûn). Mereka berbeda dalam memberikan interpretasi terhadap Hadîts Rasulullah yang mengatakan:

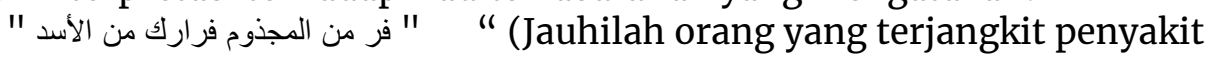
lepra sebagaimana kamu menjauhi singa) ". Dan para Shahabat yang ikut dalam perjalanan pada saat itu memandang Hadîts ini secara tekstual, sehingga mereka berpanadangan bahwa jika mereka melintasi kawasan tersebut dianggap tidak mematuhi nasehat Rasul, menurut mereka harus mencari jalan lain agar tidak terkena thâ'ûn tersebut. Sedangkan pihak Umar bepandangan kontekstual dengan memandang bahwa Hadîts itu hanyalah sebatas anjuran agar manusia selalu berhati-hati dan waspada, namun kewaspadaan tersebut tidak akan merobah takdir Allah. 
dan diskusi antara para pemikir muslim yang pernah terjadi di Indonesia pada tahun 80-an sehubungan dengan masalah bunga bank, pembagian harta waris, menggambarkan realitas tersebut.

Jika kita melihat jauh ke belakang, secara historis bukti kongkrit yang menunjukkan pola interpretasi kontekstual terhadap Hadis Nabi sudah diterapkan oleh sebagian para shahabat justru pada masa Baginda Rasul masih hidup. Merujuk kepada sikap Nabi yang menerima perbedaan pendapat di kalangan sahabat, menggambarkan bahwa sikap keterbukaan dalam menafsirkan hadist, bisa diterima dan diterapkan dalam rangka menjawab persoalan sosial. 


\section{DAFTAR PUSTAKA}

Abdullah, Amin Islamic Studies di Perguruan Tinggi: Pendekatan Integratif-Interkonektif (Yogyakarta: Pustaka Pelajar, 2012), hlm, 104 .

Al-Bukhâri, Shahîh al-Bukhârî, Juz 2 , (Kairo: Mathba'ah Salafîyah, 1990)

Afwadzi, Beni, Membangun Integrasi Ilmu-Ilmu Sosial dan Hadis

Nabi, dalam Jurnal Living Hadis, 1.1 (2016), 101-127

Bagus, Lorens, Kamus Filsafat (Jakarta: PT. Gramedia Pustaka Utama, 2002)

Nasution, Harun Islam Rasional, (Bandung: Mizan, 1995)

Syihab, Quraisy, Membumikan al-Qur 'an, (Bandung: Mizan, 1998)

Lakspesdam NU, Tashwirul Afkar, Jurnal, edisi 8.

Lajnah Ta'lif, Ahkamul Fuqaha'

Permono, Sjechul Hadi, Dinamisasi Hukum Islam dalam Menjawab

Tantangan Era Globalisasi (Kudus: Pustaka Firdaus, 1998)

, Pembaruan Hukum Islam di Indonesia,

Makalah disampaikan pada Konferensi Nasional Kajian Islam di Indonesia Tahun 2004 di Banda Aceh, tidak diterbitkan

Qaradhāwī, Yūsuf, Kaifa Nata'āmal ma'a al-Sunnah al-Nabawiyah (USA: al-Ma'had al-Ālamī li al-Fikrī al-Islamī, 1990), 